\title{
Protein content of cattle oocytes and embryos from the two-cell to the elongated blastocyst stage at day 16
}

\author{
M. Grealy, M. G. Diskin and J. M. Sreenan ${ }^{*}$ \\ Animal Reproduction Department, Agriculture and Food Development Authority, Belclare, Tuam, \\ Co. Galway, Ireland
}

\begin{abstract}
The protein content of cattle oocytes and preimplantation embryos produced in vivo, from the two-cell to the elongated blastocyst at day 16, was determined. From the oocyte to the expanded blastocyst stage (day 8), protein determination was carried out on zona pellucida-enclosed embryos. Protein content was measured by the Pierce Micro BCA protein assay. The mean protein content of oocytes was $0.126 \mu \mathrm{g}$, with no significant increase at the two-cell stage $(0.132 \mu \mathrm{g})$. Protein content was higher at the morula stage $(0.183 \mu \mathrm{g} ; P<0.05)$ with a further increase at the expanded blastocyst stage $(0.367 \mu \mathrm{g}$; $P<0.05$ ). There was a 160 -fold increase in protein content from the expanded blastocyst to the hatched day 13 stage. Spherical, ovoid and elongated blastocysts were collected on days 13 and 14 . The mean protein content of day $13(59.8 \mu \mathrm{g})$ and day $14(92.4 \mu \mathrm{g})$ embryos was similar $(P>0.1)$, but the protein content of the elongated embryos was higher than that of ovoid or spherical embryos collected on the same day. Protein content of day 15 embryos $(362.2 \mu \mathrm{g})$ was higher than that on day 14 , with a further increase to $946.6 \mu \mathrm{g}$ by day 16 . The correlation between protein content and day of development contained both a linear and a quadratic component. Embryo length and width increased from day $13(5.24 \mathrm{~mm}$ and $0.89 \mathrm{~mm}$, respectively) to day $16(51.6 \mathrm{~mm}$ and $1.82 \mathrm{~mm}$, respectively). From day 13 to day 16 , the protein content was correlated with both embryo length and width $\left(r^{2}=0.89\right.$ and 0.51 , respectively; $P<0.001)$ and was highly correlated $\left(r^{2}=0.95\right)$ with the product of embryo length by width, indicating that protein content increases as a function of surface area.
\end{abstract}

\section{Introduction}

A major problem faced by the cattle breeding industry is the high rate of embryo mortality which compromises reproductive efficiency, genetic improvement and the development and exploitation of embryo-related biotechnology. After a single insemination, fertilization rate is about $90 \%$, but calving rate is only about $55 \%$, with more than $30 \%$ of embryos lost by day 16 (Diskin and Sreenan, 1980). To address this problem of early embryo death and to enhance the supply of cattle embryos for in vitro fertilization it is vital to obtain a better understanding of normal embryo development. Knowledge of the protein content of embryos, from fertilization to development of the blastocyst, is essential for the interpretation of information arising from studies on parameters, such as energy metabolism (Rieger and Guay, 1988) and protein synthesis (Frei et al., 1989), that are involved in the control of embryo development. However, while information is available on the protein content of the preimplantation embryos of mice (Brinster, 1967; Schiffner and Spielmann, 1976; Sellens et al., 1981), rats (Schiffner and Spielmann, 1976), rabbits (Morgan and Kane,

*Correspondence.

Received 22 December 1995.
1993) and pigs (Anderson, 1978; Wright et al., 1981, 1983), such information has not been published for cattle embryos. We have therefore measured the protein content of cattle oocytes and of preimplantation embryos produced in vivo from the two-cell to the elongated blastocyst stage.

\section{Materials and Methods}

\section{Embryos and oocytes}

Hereford-cross heifers were used as donors of the embryos produced in vivo. Each heifer received 1500 iu of pregnant mares' serum gonadotrophin i.m. (Folligon, Intervet UK Ltd, Cambridge) during the mid-luteal phase of the oestrous cycle (days 10-14) and $500 \mu \mathrm{g}$ cloprostenol (Estrumate, Coopers Animal Health Ltd, Berkhamsted) $48 \mathrm{~h}$ later to induce luteolysis. From $48 \mathrm{~h}$ after administration of cloprostenol the heifers were continuously checked for overt signs of oestrus and those observed at the onset of oestrus were artificially inseminated with semen from one sire. Embryo recovery was carried out during mid-ventral laparotomy performed under licence in accordance with the European Community Directive, 86-609EC. Thiopentone sodium ( 5 g, i.v.; Rhone Merieux, Harlow) 
was used as anaesthetic followed by closed circuit anaesthesia with halothane (May and Baker Ltd, Dagenham) and oxygen. To obtain embryos at the two-cell stage, each oviduct was flushed with $20 \mathrm{ml}$ medium between 44 and $54 \mathrm{~h}$ after the onset of standing oestrus. Morulae, mid-blastocyst and expanded blastocyst stages were flushed from the uterus at 6,7 and 8 days after the observed onset of standing oestrus, while hatched and elongated blastocysts were flushed from the uterus at days 13 , 14, 15 and 16. The composition of the flushing medium was $0.1 \%(\mathrm{w} / \mathrm{v})$ polyvinyl alcohol, $139 \mathrm{mmol} \mathrm{NaCl} \mathrm{l}^{-1}, 2.7 \mathrm{mmol}$ $\mathrm{KCl} \mathrm{1^{-1 }}, 0.89 \mathrm{mmol} \mathrm{CaCl} \cdot 2 \mathrm{H}_{2} \mathrm{O} \mathrm{l^{-1 }}, 1.47 \mathrm{mmol} \mathrm{KH_{2 }} \mathrm{PO}_{4}$ $1^{-1}, \quad 0.49 \mathrm{mmol} \quad \mathrm{MgCl}_{2} \cdot 6 \mathrm{H}_{2} \mathrm{O} \quad 1^{-1}, \quad 7.46 \mathrm{mmol}$ $\mathrm{Na}_{2} \mathrm{HPO}_{4} \cdot 2 \mathrm{H}_{2} \mathrm{O} 1^{-1}$, $1 \mathrm{mmol}$ glucose $1^{-1}$ and $0.5 \mathrm{mmol}$ pyruvic acid (sodium salt) $\mathrm{l}^{-1}, \mathrm{pH}$ 7.3. After recovery, embryos were graded for viability on a morphological scale from 1 (excellent) to 5 (degenerate) according to Hasler et al. (1987) for two-cell to expanded blastocyst stages. Viability of hatched and elongated blastocysts was based on morphological appearance and expected developmental stage for age. Only grade 1 and 2 embryos were included in the study. Length and width of the blastocysts at day 13 to 16 were measured using a graticule on a stereoscopic microscope for measurements under $2 \mathrm{~mm}$ or directly with a calibrated rule for larger embryos. Embryos were designated spherical when the length and width were approximately equal, ovoid when the length was more than 1.5 times the width but was less than $1 \mathrm{~cm}$, or elongated when the length was more than five times the width and was longer than $1 \mathrm{~cm}$. Surface area could not be estimated using the standard formula for a sphere or a cylinder, because from day 13 cattle embryos tend to be ribbon-like rather than perfect spheres or cylinders. However, length $\times$ width is always a component of total surface area of an object of general cylindrical, spherical or ovoid form and was used as an index of surface area. Only intact embryos were used in the study. Embryos were washed three times in the same flushing medium but from which the glucose was omitted to avoid interference with the protein assay. Embryos were transferred to $200 \mu \mathrm{l} 95 \%$ ethanol (Merck, Darmstadt) in $1.5 \mathrm{ml}$ conical plastic tubes (Safe-twist, Eppendorf, Hamburg) which were stored in liquid $\mathrm{N}_{2}$ until assay. At least nine oocytes and pre-blastocyst stage embryos or four blastocysts or two expanded blastocysts were pooled for each determination to ensure enough protein to give an accurate reading. From day 13 onwards hatched embryos were assayed singly for protein content.

Oocyte collection was carried out by aspiration of follicles of 2-8 $\mathrm{mm}$ diameter from cattle ovaries obtained at a local abattoir. Ovaries were transported to the laboratory in saline $(0.9 \%(\mathrm{w} / \mathrm{v}) \mathrm{NaCl})$ maintained at $30-35^{\circ} \mathrm{C}$. Follicle aspiration was performed with a $10 \mathrm{ml}$ syringe and an 18-gauge needle and the aspirated fluid was transferred to a small Petri dish and examined under a stereoscopic microscope $(\times 10)$ for oocytes. Denuded oocytes and those with expanded cumulus were discarded. Oocytes with at least three layers of cumulus cells were transferred to a $15 \mathrm{ml}$ conical tube containing $2 \mathrm{ml}$ flushing medium and vortexed for $5 \mathrm{~min}$ to remove cumulus cells. Cumulus-free oocytes were then selected, washed in the glucose-free medium and stored in the same way as embryos recovered in vivo. Samples of the final washing solution were also similarly stored for each group and used as blanks in the protein assay.

\section{Protein determination}

Embryos and oocytes were thawed at room temperature and sonicated in their storage tubes by exposure to sonication bursts of $6 \mathrm{~s}$ until visibly disrupted when examined under the microscope $(\times 10)$. Disruption required several sonication bursts for oocytes and zona-enclosed embryos, while one burst was sufficient for the hatched embryos. Oocyte and embryo tissue samples were then centrifuged at $12000 \mathrm{~g}$ for $15 \mathrm{~min}$. After centrifugation the supernatant was poured off and the pellet was washed once with $200 \mu \mathrm{l} 95 \%$ ethanol and centrifuged again. Tubes containing blanks were treated and stored in a similar manner.

Protein in the pellet was estimated using the Pierce Micro BCA assay (Pierce and Warriner Ltd, Chester) as described by Morgan and Kane (1993). Protein standards containing $0.5-10 \mu \mathrm{g}$ BSA per $0.5 \mathrm{ml}$ distilled $\mathrm{H}_{2} \mathrm{O}$ were prepared. Standards and oocyte and embryonic tissue samples were hydrolysed with $5 \mu \mathrm{l} 10 \mathrm{~mol} \mathrm{NaOH} \mathrm{l}{ }^{-1}$, for $30 \mathrm{~min}$ at $56^{\circ} \mathrm{C}$ and neutralized with $10 \mu \mathrm{l} 5 \mathrm{~mol} \mathrm{HCl} \mathrm{l}^{-1}$. The hydrolysed material was diluted to a final volume of $500 \mu \mathrm{l}$. For stages from oocyte to expanded blastocyst the total volume was assayed, while for day 13-16 stages, aliquots of $5-100 \mu \mathrm{l}$ were assayed in duplicate using the protocol supplied with the kit.

\section{Statistical analyses}

Data on the protein content of oocytes and early embryo stages up to the expanded blastocyst were analysed by analysis of variance (Proc GLM, SAS, 1988) followed by Duncan's multiple range test. The hatched embryos collected from day 13 onwards had a protein content more than 160 times that of the pre-hatched expanded blastocysts; therefore, the data were analysed separately. In this case, the protein content data were $\log$ transformed and analysed by analysis of variance followed by Duncan's multiple range test where appropriate. Day was fitted as a linear and quadratic term in the model. Results are presented as arithmetic means and ranges. The effect of recovery day (day 13-16) on embryo length and width and the relationship between embryo length, width and protein content were analysed by analysis of variance with linear and quadratic terms fitted where appropriate.

\section{Results}

Protein content was similar for oocytes and two-cell stages. It was higher $(P<0.05)$ at the morula and blastocyst stages, for which the results were similar, and was highest $(P<0.05)$ at the expanded blastocyst stage (Table 1).

Between days 13 and 16 , the protein content increased in a linear $(P<0.001)$ and quadratic $(P<0.001)$ manner (protein content $(\mu \mathrm{g}$ per embryo $)=23518-3508($ day $)+131(\text { day })^{2}$; $r^{2}=0.69$ ) (Table 2). Between days 13 and 16 , embryo length also increased in a linear $(P<0.001)$ and quadratic $(P<0.001)$ manner (embryo length $(\mathrm{mm})=1109-166.86$ (day) +6.30 $\left.(\text { day })^{2} ; r^{2}=0.63\right)$, while embryo width increased in a linear $(P<0.001)$ manner (embryo width $(\mathrm{mm})=-2.31+0.255$ (day); $r^{2}=0.31$ ). The protein content increased linearly and quadratically $(P<0.001)$ with embryo length (protein content 
Table 1. Protein content of cattle oocytes and pre-hatched embryos

\begin{tabular}{|c|c|c|c|c|}
\hline Stage & $\begin{array}{c}\text { Number of } \\
\text { oocytes or } \\
\text { embryos }\end{array}$ & $\begin{array}{l}\text { Number of } \\
\text { oocytes or } \\
\text { embryos } \\
\text { per replicate }\end{array}$ & $\begin{array}{l}\text { Number of } \\
\text { replicates }\end{array}$ & $\begin{array}{l}\text { Protein }(\mu \mathrm{g}) \\
\text { per oocyte } \\
\text { or embryo } \\
\text { (mean } \pm \text { SEM) }\end{array}$ \\
\hline Oocytes & 115 & $9-11$ & 12 & $0.126 \pm 0.0059^{a}$ \\
\hline $\begin{array}{l}\text { Two-cell } \\
\text { (day 2) }\end{array}$ & 67 & $8-14$ & 5 & $0.132 \pm 0.0196^{a}$ \\
\hline $\begin{array}{l}\text { Morula } \\
\text { (days 6-7) }\end{array}$ & 62 & $8-14$ & 7 & $0.183 \pm 0.0203^{b}$ \\
\hline $\begin{array}{l}\text { Blastocyst } \\
\text { (days } 7-8 \text { ) }\end{array}$ & 40 & $4-10$ & 6 & $0.185 \pm 0.0158^{b}$ \\
\hline $\begin{array}{l}\text { Expanded blastocyst } \\
\text { (day 8) }\end{array}$ & 12 & $2-4$ & 5 & $0.367 \pm 0.0277^{\mathrm{c}}$ \\
\hline
\end{tabular}

Values with different superscripts are significantly different $(P<0.05)$

Table 2. Protein content and size of hatched cattle blastocysts recovered on different days after oestrus

\begin{tabular}{|c|c|c|c|c|}
\hline Day & $\begin{array}{l}\text { Number of } \\
\text { embryos }\end{array}$ & $\begin{array}{l}\text { Length } \\
(\mathrm{mm})\end{array}$ & $\begin{array}{l}\text { Width } \\
(\mathrm{mm})\end{array}$ & $\begin{array}{l}\text { Protein } \\
(\mu g)\end{array}$ \\
\hline 13 & 18 & $\begin{array}{c}5.24 \pm 0.869 \\
(0.8-13.3)\end{array}$ & $\begin{array}{c}0.89 \pm 0.048 \\
(0.58-1.3)\end{array}$ & $\begin{array}{cc}59.8 \pm & 8.19 \\
(3.0-140.8)\end{array}$ \\
\hline 14 & 37 & $\begin{array}{c}7.84 \pm 1.801 \\
(0.8-55.0)\end{array}$ & $\begin{array}{c}1.1 \pm 0.037 \\
(0.7-1.7)\end{array}$ & $\begin{array}{c}92.4 \pm 21.35 \\
(5.7-701.4)\end{array}$ \\
\hline 15 & 12 & $\begin{array}{c}25.08 \pm 3.636 \\
(6.0-43.0)\end{array}$ & $\begin{array}{c}1.28 \pm 0.134 \\
(0.5-1.8)\end{array}$ & $\begin{array}{c}362.2 \pm 73.16 \\
(74.7-741.2)\end{array}$ \\
\hline 16 & 5 & $\begin{array}{c}51.6 \pm 3.816 \\
(40.0-60.0)\end{array}$ & $\begin{array}{c}1.82 \pm 0.296 \\
(1.0-2.5)\end{array}$ & $\begin{array}{l}946.6 \pm 135.76 \\
(613.2-1385.3)\end{array}$ \\
\hline
\end{tabular}

Values are means \pm SEM.

Figures in parentheses are the range.

$(\mu \mathrm{g}$ per embryo $)=9.65+8.35$ (embryo length $\mathrm{mm})+0.16$ (embryo length) $)^{2} ; r^{2}=0.89$ ). Protein content also increased linearly $(P<0.001)$ with embryo width (protein content $(\mu \mathrm{g}$ per embryo) $=-408.4+524.3$ (embryo width $\mathrm{mm}) ; r^{2}=0.51$ ). The relationship between protein content, embryo length and width is described by the equation (protein content $(\mu \mathrm{g}$ per embryo) $=12.37+9.57$ (embryo length $\mathrm{mm}$ ) (embryo width $\mathrm{mm}$ ) and is graphically presented (Fig. 1). The coefficient of determination $\left(r^{2}\right)$ was 0.95 , indicating that only $5 \%$ of the observed variation in protein content was due to sources other than embryo length and width.

Within days 13 and 14 there was a large variation in size, shape and protein content of the embryos recovered (Table 3). Spherical, ovoid and elongated embryos were recovered on each of these days and there was a day $\times$ embryo developmental stage interaction on protein content; spherical embryos collected on day 14 had a higher protein content than did spherical embryos collected on day $13(P<0.05)$. Ovoid and elongated embryos collected on day 13 had similar protein contents to ovoid and elongated embryos collected on day 14 respectively $(P>0.1)$. Protein content was higher in ovoid embryos (day 13 and day 14) than in spherical embryos and higher again in elongated embryos $(P<0.05)$.

\section{Discussion}

This is the first report of the protein content of cattle oocytes and embryos, from the two-cell stage to the elongated blastocyst stage at day 16 . There is a relatively small increase in protein content from the oocyte to the blastocyst stage, while the zona-enclosed expanded blastocyst had a protein content approximately twice that of the blastocyst. There was a marked increase (160-fold) in the protein content of hatched blastocysts recovered on day 13 compared with the zona-enclosed expanded blastocyst. From day 13 to day 16 the protein content increased exponentiaily.

The protein content $(0.132 \mu \mathrm{g})$ of the two-cell cattle embryos presented here is large compared with that reported for rats $(0.032 \mu \mathrm{g}$; Schiffner and Spielmann, 1976) and mice $(0.026 \mu \mathrm{g}$; Brinster, 1967; Schiffner and Spielmann, 1976), is similar to rabbits $(0.17 \mu \mathrm{g}$; Morgan and Kane, 1993) and is 


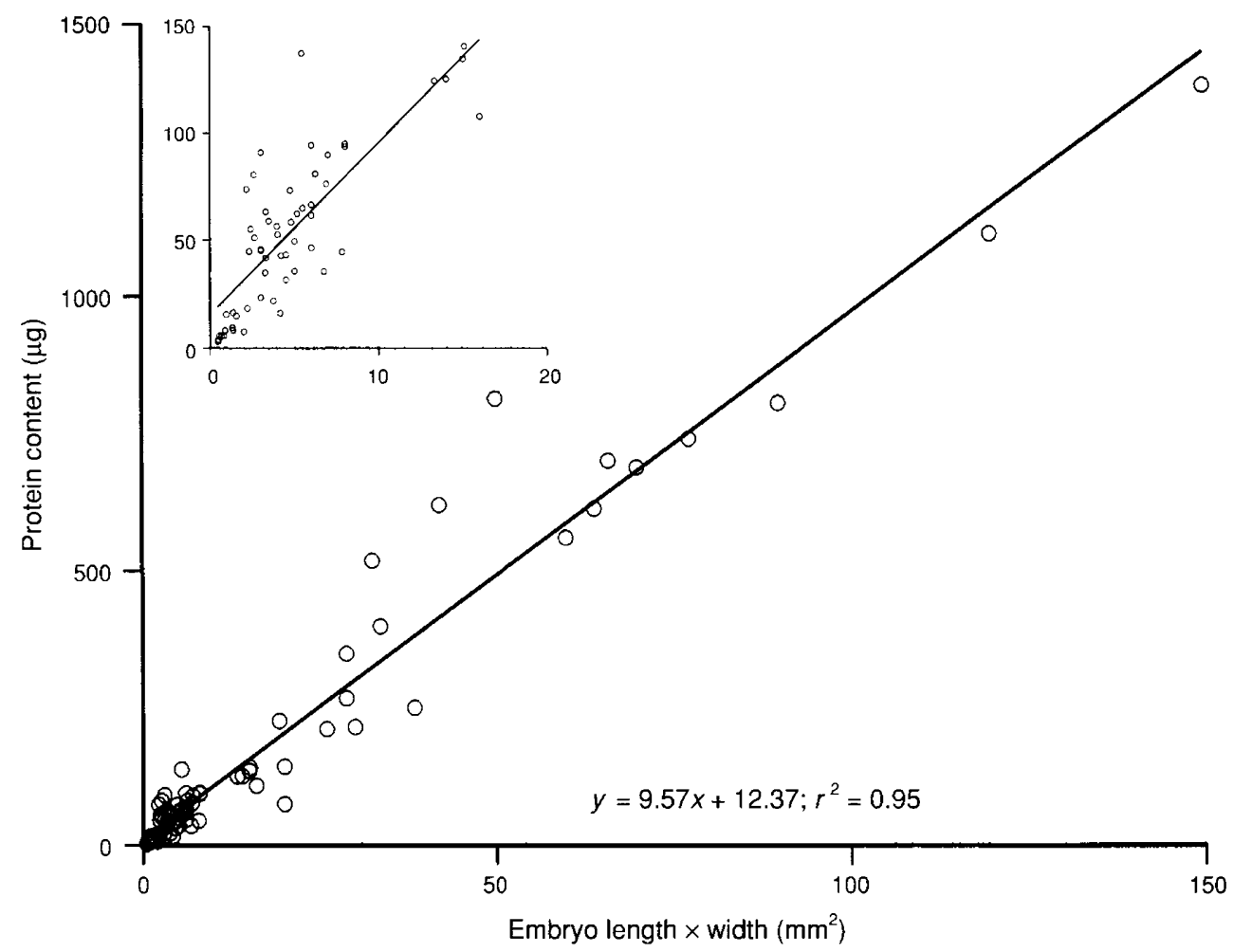

Fig. 1. Protein content of hatched cattle blastocysts recovered on days 13-16 expressed as a function of blastocyst length $\times$ diameter. Insert shows in detail results for smaller embryos $(<150 \mu \mathrm{g}$ protein).

Table 3. Protein content and size of cattle blastocysts recovered on days 13 and 14 by developmental stage

\begin{tabular}{lcccc}
\hline Day & Stage & $n$ & $\begin{array}{c}\text { Length } \\
(\mathrm{mm})\end{array}$ & $\begin{array}{c}\text { Protein } \\
(\mu \mathrm{g})\end{array}$ \\
\hline 13 & Spherical & 4 & $0.89 \pm 0.005$ & $4.51 \pm 0.661^{\mathrm{a}}$ \\
& Ovoid & 12 & $5.48 \pm 0.612$ & $66.08 \pm 4.881^{\mathrm{c}}$ \\
& Elongated & 2 & 12.45 & 132.7 \\
& & & $(11.6,13.3)$ & $(140.8,124.6)^{\mathrm{d}}$ \\
& Spherical & 9 & $1.42 \pm 0.159$ & $12.47 \pm 1.538^{\mathrm{b}}$ \\
& Ovoid & 20 & $4.04 \pm 0.348$ & $56.98 \pm 5.731^{\mathrm{c}}$ \\
& Elongated & 8 & $24.58 \pm 4.922$ & $270.67 \pm 67.884^{\mathrm{d}}$ \\
\hline
\end{tabular}

Values given are means \pm SFM.

Values with different superscripts are significantly different $(P<0.05)$.

lower than that reported for pigs $(0.273 \mu \mathrm{g}$; Wright et al., 1981). The significant increase in protein at the expanded blastocyst stage is similar to data reported for rabbits (Morgan and Kane, 1993) and pigs (Wright et al., 1981) and is consistent with the increase in embryo size. The diameter of the expanded cattle blastocyst is about 1.2-1.5 times that of the blastocyst (Lindner and Wright, 1983) and contains about 160 cells compared with about 120 cells in the blastocyst (Mannaerts, 1986). The increase in protein content at this stage differs, however, from that of mice and rats, in which embryonic protein content decreases between the one-two-cell and morula-blastocyst stages (Brinster, 1967; Schiffner and Spielmann, 1976). The significant increase in protein content from the two-cell to the morula stage, with a further increase at the expanded blastocyst stage, reported here is consistent with the increase in protein synthesis recorded at these stages by Frei et al. (1989). Increases in pyruvate uptake and ATP production (Thompson et al., 1996) and glucose metabolism (Javed and Wright, 1991; Rieger et al., 1992) are also consistent with the marked increase in protein content reported here, as they reflect the energy requirement of protein synthesis.

Between day 13 and day 16, embryo protein content increased in a linear and quadratic fashion, consistent with the linear and quadratic increase for embryo length, and the linear increase in embryo width recorded over this time. After hatching, cattle embryos begin a phase of rapid growth before implantation with a period of exponential growth between spherical blastocysts on day 13 and elongated blastocysts on day 16 (Betteridge et al., 1980), and this is reflected in the linear and quadratic nature of the relationship between embryo protein content and day of development presented here. Implantation in cattle occurs later than in pigs and, therefore, the developmental stages are not equivalent. However, cattle embryos recovered on day 13 in the present study were similar in shape, size and protein content to pig embryos at day 10 , while the results reported here for cattle embryos recovered on days 15-16 were similar to those reported for pig embryos recovered on day 11 by Anderson (1978).

There was significant within-day variation in the size, shape and protein content of the cattle embryos with spherical, ovoid and elongated embryos recovered at days 13 and 14. At days 15 and 16, the embryos were elongated but with great variation in length within days. This variation in size and shape 
is not unique to superovulated embryos; a similar variation in the embryos of single-ovulating heifers has been reported by Betteridge et al. (1980). The variation in size and shape of embryos at the hatched stages is also consistent with the data on pigs reported by Anderson (1978).

The significant correlation between embryo length and protein content between day 13 and day 16 is similar to that reported by Anderson (1978) for pigs. However, Wright et al. (1983), in a subsequent study, failed to find a correlation between protein content and volume of pig blastocysts. In the study reported here, protein content increased with both embryo length and width, suggesting a positive correlation between embryo surface area and protein content. Some caution is required, however, in interpreting the data for width of day 13 to day 16 blastocysts, as the width is extremely difficult to measure accurately due to the folded nature of the elongated cattle blastocyst.

Proportionately more elongated embryos fragmented at days 15 and 16 than at days 13 or 14 , indicating that the larger embryos have a greater tendency to fragment. The protein content of day 15 and day 16 embryos reported here is for intact embryos and may therefore represent the smaller embryos recovered on those days.

A knowledge of the protein content of normal preimplantation cattle embryos is necessary as a basis for interpretation of in vitro culture data, metabolic and protein synthesis studies. It is also an important parameter in the assessment of embryo growth and viability, particularly at the critical stage between blastocyst formation and elongation, when maternal recognition of pregnancy occurs and indeed when most embryo loss occurs.

This work was supported by the EC Biotech 3rd Framework Programme (Contract BIO2-CT-92-0163). The authors thank J. P. Hanrahan for statistical advice, M. T. Kane for constructive criticism, A. Glynn, P. Joyce, J. Nally, G. Morris and W. Connolly for technical support and G. Burke and P. Creaven for care of the animals.

\section{References}

Anderson LL (1978) Growth, protein content and distribution of early pig embryos Anatomical Record 190 143-154
Betteridge KJ, Eaglesome MD, Randall GCB and Mitchell D (1980) Collection, description and transfer of embryos from cattle 10-16 days after oestrus Journal of Reproduction and Fertility 59 205-216

Brinster RL (1967) Protein content of the mouse embryo during the first five days of development Journal of Reproduction and Fertility 13 413-420

Diskin MG and Sreenan JM (1980) Fertilization and embryonic mortality rates in beef heifers after artificial insemination Journal of Reproduction and Fertility 59 463-468

Frei RE, Schultz GA and Church RB (1989) Qualitative and quantitative changes in protein synthesis occur at the 8-16-cell stage of embryogenesis in the cow Journal of Reproduction and Fertility $86637-641$

Hasler JF, McCauley AD, Lathrop WF and Foote RH (1987) Effect of donorembryo-recipient interactions on pregnancy rate in a large-scale bovine embryo transfer program Theriogenology 27 139-168

Javed MH and Wright RWJ (1991) Determination of pentose phosphate and Embden-Meyerhof pathway activities in bovine embryos Theriogenology 35 1029-1037

Lindner GM and Wright RW (1983) Bovine embryo morphology and evaluation Theriogenology 20 407-416

Mannaerts BMJL (1986) Cytological parameters for rating bovine embryo quality Current Topics in Veterinary Medicine and Animal Science 34 216-222

Morgan PM and Kane MT (1993) Protein content of rabbit embryos: one cell to peri-implantation blastocyst Journal of Reproduction and Fertility 97 101-106

Rieger D and Guay P (1988) Measurement of the metabolism of energy substrates in individual bovine blastocysts Journal of Reproduction and Fertility $83585-591$

Rieger D, Loskutoff NM and Betteridge KJ (1992) Developmentally related changes in the uptake and metabolism of glucose, glutamine and pyruvate by cattle embryos produced in vitro Reproduction Fertility and Development 4 $547-557$

Schiffner J and Spielmann H (1976) Fluorometric assay of the protein content of mouse and rat embryos during preimplantation development Journal of Reproduction and Fertility 47 145-147

Sellens MH, Stein S and Sherman MI (1981) Protein and free amino acid content in preimplantation mouse embryos and in blastocysts under various culture conditions Journal of Reproduction and Fertility 61 307-315

Thompson JG, Partridge RJ, Houghton FD, Cox CI and Leese HJ (1996) Oxygen uptake and carbohydrate metabolism by in vitro derived bovine embryos Journal of Reproduction and Fertility 106 299-306

Wright RW, Grammer J, Bondioli K, Kuzan F and Menino A (1981) Protein content of porcine embryos during the first nine days of development Theriogenology 15 235-239

Wright RW, Grammer J, Bondioli K, Kuzan F and Menino A (1983) Protein content and volume of early porcine blastocysts Animal Reproduction Science 5 207-212 